\title{
Persuading the Public: Ranking of Bidayuh's Home-stays Websites
}

\author{
Mus Chairil Samani ${ }^{1}$, Jamilah Maliki ${ }^{1}$, Tracy Peter Samat ${ }^{2} \&$ Nurul Huda Marwan ${ }^{3}$ \\ ${ }^{1}$ Department of Communication, Faculty of Language and Communication Studies, Universiti Malaysia \\ Sarawak, Malaysia \\ ${ }^{2}$ Department of Anthropology and Sociology, Faculty of Social Sciences, Universiti Malaysia Sarawak, \\ Malaysia \\ ${ }^{3}$ Department of International Studies, Faculty of Social Sciences, Universiti Malaysia Sarawak, Malaysia \\ Correspondence: Mus Chairil Samani, Department of Communication, Faculty of Language Studies and \\ Communication Studies, Universiti Malaysia Sarawak (Unimas), Malaysia. E-mail: smchairil@unimas.my
}

Received: January 20, 2016

doi:10.5539/ass.v12n12p20

\author{
Accepted: February 14, 2016 Online Published: October 29, 2016
}

URL: http://dx.doi.org/10.5539/ass.v12n12p20

\begin{abstract}
In this age of the new media, everyone with access to the Internet and knowledge can build their own website to market their services or products to the general public. One group of people who are harnessing the powers of the Internet is individual home-stays operators. Home-stays operators can advertise their services to the general public, either locally or internationally through the Internet. This paper explores the types of contents created by the Bidayuh people who are home-stays entrepreneurs at the Annah Rais longhouse located in the Padawan District, Sarawak. A search on the Internet indicates that three operators have their own websites to advertise their home-stays. To obtain information about the services and packages offered by these Bidayuh operators, the three home-stay websites were content analyzed. The analysis involves ranking these websites with a purposely created ranking instrument. Analysis of the data show that these home-stays operators obtained an above average score on all indicators. In other words, potential visitors will have sufficient knowledge about each home-stay if they were to surf the respective websites. Knowledge about the location, accommodation, types of packages and modes of reservation are offered to entice would be visitors to the Annah Rais longhouses.
\end{abstract}

Keywords: new media, ranking, home-stays, advertise, Bidayuh

\section{Introduction}

The advent of Internet has allowed both private and public organisations to advertise their products and services to the world. The opportunities made possible by the Internet are not only harnessed by these organisations but also small scale home-stays operators. This paper studies of websites created by home-stays owners that are operated by the Bidayuh tribe in Annah Rais, Sarawak. The Bidayuh is one of more than 34 indigenous peole living in the state of Sarawak (Jeniri, 2015).

Annah Rais longhouses are situated in Padawan district located about $65 \mathrm{~km}$ from Kuching, the state capital of Sarawak, Malaysia. The journey by car to the village from the city is approximately one hour and 45 minutes. The village is situated on both banks of the Simadang River and has existed for 286 years. The number of village population is 1,218 people based on the village profile which is last updated in August, 2008 (Samat, 2012). Out of the populations, Bidayuh community represents the largest population with 1,149 people, followed by the Chinese ethnic group with 50 people, 15 people from Iban ethnic group and the remaining four people whose ethnic background are unrecorded. Majorly, the Bidayuh people are the Biannah sub-group who speak Bidayuh Biatah dialect (Samat, 2012).

The village settlement at Annah Rais is in a form of cluster. There are two types of houses in the village; the longhouses with 64 "bilik" (apartments) and about 85 individual separate houses scattered along the banks of the river and on the higher ground of the settlement. The longhouses are as old as eight generations and are divided into three sections: Kupo Sebak, Kupo Terakan and Kupo Sijok (Samat, 2012).

Annah Rais was opened for tourism in 1990 but the home-stay industry only started to operate in 2006 . As of today, there are 14 families running the home-stay businesses in the village but not all of these proprietors are using the Internet to advertise their services. Currently there are only three home-stays operators that have 
created their own websites to advertise their services. The home-stays websites are:

- Annah Rais Bidayuh Homestay $<\mathrm{http}: / / \mathrm{www}$.longhouseinborneo.com/>

- Annah Rais Longhouse Adventure $<\mathrm{http}$ ://www.longhouseadventure.com/ $>$

- Bidayuh Annah Rais Longhouse Homestay <http://bidayuhlonghouse.blogspot.com/>

The websites of two of the home-stays operators are being hosted on two different registered domains. The owners of these websites have registered their domains with the respective website hosting providers. Registering with website hosting providers will incur an annual fee for as long as the site remains active. The distinct advantage of registered domains is it will be displayed more prominently by Internet search engines. These websites will usually appear on the first page for each search result if an Internet user was to search using selected words that appear on the website domain.

The third home-stays operator took a different route by hosting its website on blogspot.com. This is cheaper and does not incur any recurring financial cost. The setback is that the administrator of blogspot.com can insert adverts without any notice to the owner of the blog. Whichever route they take to host their respective websites, these home-stays operators share similar intent that is to advertise their services to potential clients locally or internationally.

Researches on the Internet have mostly focused on the content developed by large commercial entities. The current study looks at the information provided by small scale business operators using the new media. Internet as a marketing medium has been widely studied (Lin \& Huang, 2006). This study looks at the content provided by small-scale home-stays operators who are limited by capital but not necessarily lacking in knowledge about the business potential of using the Internet.

These small scale business operators usually start off as Internet users before embarking on creating their own content to exhibit their goods and services. With the Internet, they no longer need the services of big mass media companies to advertise their services. They are going direct to their potential clients and thus circumventing the need for mass media operators. By doing so, these operators do not incur extra cost and they have total control on the information provided on their websites. Websites offer another distinct advantage that is updating of the information instantaneously and continuously (Huang \& Ho, 2015). To the website operators, they hold the amount and type of information that they are willing to share with their potential clients. To the users, they will have to rely on their own individual judgment to rate the usefulness and suitability of the information offered. Expert users of Internet are well aware that some information providers offer inaccurate, bias and misleading information. These content providers are either doing it intentionally or unintentionally. They are able to do this because publishing on the Internet is different from the traditional media (Mus Chairil, 2012).

With traditional news media, several people are involved in the publishing process (Mus Chairil et al., 2011). Anything publishable on the traditional news media will go through several layers of editing. This is to determine the accuracy and objectivity of the information provided. The person with the information is not related to the person who is creating, editing and publishing the information. With the Internet, the same person will be multi-taskings several tasks. In other words, the same person acts as the content provider, creator and publisher. The laymen are not tied to specific code of conduct such as journalists who are working for a mass media. Thus, their value judgment is not morally tied to any particular profession.

These content providers are fully cognizant that the information they provide can reach potential clients that transcend physical boundaries. Thus, they can seek out foreign and local clients with little or no effort. Samat et al. (2014) in their studies on the tourists who are frequenting these home-stays found that they are both local and abroad. The people who had visited Annah Rais confirmed that the Internet was their first choice for seeking information about these home-stays.

Visitors to a foreign place usually rely on several options to determine whether the place for a proposed visit is suitable to their needs. The best form of recommendation usually comes from a person who had visited the place. They will always be asked to give a subjective rather than an objective opinion on that particular place. People tend to place higher value to endorsement given by close friends or relatives.

If these types of recommendations are not available, people will often scan the mass media for materials and information about a prospective site (Flanagin \& Metzger, 2000). The mass media such as newspapers and tourism related magazine offer an "objective" evaluation of a particular site. The people who use these printed mass media rely on the objective rating offered by the journalists who usually write based on their first-hand experiences visiting a particular tourism site (Mus Chairil et al., 2013). 
Research on home-stays is nothing new. One such studies measure the experiential aspect of staying at home-stays run by Malay in the rural areas (Ghazali et al., 2009). The method involved keeping a diary on their day-to-day experience. Baty and Dold (1977) were interested to study the effects of staying at home-stays on a group of college students. Hokanson (2000) was interested in studying the potential of acquiring a foreign language while staying at a home-stays program.

Another study in Singapore looks at the potential of home-stays as an alternative mode of accommodation to the city state (Loke et al., 2004). Yahaya (2004) discusses the prospect of home-stays in the Malaysian tourism industry. Amran (2008) in his study looks at how home-stays programs in Malaysia have evolved into a mainstream tourism product. The product is also aimed at revitalizing the rural Malaysian economy. A similar study was done by Wall et al. (1996). Their study looks at the prospect of residents of Bali to become entrepreneur in a tourism related industry.

Based on previous studies, the purpose of this paper seeks to analyze the richness of the content of home-stays websites that were created by operators of home-stays at longhouses at Annah Rais, Padawan District in Sarawak, Malaysia. The analysis requires the researchers to develop a purposely created instrument to ascertain the richness of information provided on these websites. The amount and quality of information provided on websites are measured to ascertain its usefulness to potential visitors.

The analysis will ascertain the richness and breadth of the information from the users' perspective. Nielsen (2000: 11) states that the ultimate goal of most websites is "to make it easy for customers to perform useful tasks." In the case of home-stays websites, the purpose should be to make sure that the necessary information can be found with a click of a button. This will allow potential customer to make an informed decision quickly. It would be futiled to create a website if all the necessary information is not laid out appropriately. Web users have always insisted on instant gratification (Mus Chairil et al., 2011). Anything less will mean that they will surf to another site (ALsarayreh et al., 2011).

\section{Ranking and Websites}

Ranking of website is nothing new. There are many tools available to rank a website. The most common method of ranking a website is used by search engine such as Google, AltaVista, Yahoo, Excite, Infoseek and etc. Search engines will display and rank websites that it perceived to be directly related to the search query. Developers of websites are well aware of this, thus they will make sure that they are the first to register using a particular domain or name.

Most of the times, researchers will use several types of search engines to determine which website has the highest ranking. In the case of a search engine, it is normal to note that the website which is listed on the top will be ranked as the most popular. Search engines employ special software robots called spiders to catalogue the hundreds of millions of web pages available. These spiders will catalogue recurring words found in the title, subtitles and metatags. The lists of websites displayed by search engines should be read with caution. As a commercial entity, owners of websites can asked that their site be displayed predominantly for a fee.

Numerous researches have been conducted on ranking of website. Meric et al. (2002) in a study to rank website relating to breast cancer use both Google and AltaVista to generate the top 200 websites. In determining the top 200 websites, Meric et al. use the term "breast cancer" to search for sites on both search engines. To measure popularity, the researchers use two measures which are Google ranking and the number of links. They defined the first 100 websites as the "most popular" and the next 100 as "less popular". Since Google and other search engines ranked a website according to popularity, the researchers found that this should not be confused with quality of content. Quality of content is directly related to the accuracy of the information provided in the website.

Research on ranking of websites is done mostly by researchers who are in the field of computer science and information technology. Thus, they use indicators that are related to their field in ranking of websites. An example would be the study done by Tsai et al. (2010). In a study to evaluate national park websites in Taiwan, they concluded that there are 11 criteria for assessing national park websites based on previous research. The 11 criteria are navigability, speed, links, relevancy, richness, currency, attractiveness, security, personalization, and responsiveness. Although there are merits for these 11 criteria, we can argue that relevancy and richness are two overlapping criteria. Both criteria deal with depth and scope of information provided. To further compound the issue, currency adds up-to-date information to the depth and scope of information.

\section{Method for Ranking of Websites}

To study about the services and packages offered by these Bidayuh operators, the three home-stays websites 
were analyzed. Content analyzing these websites will yield information about the types of services and content that these home-stays operators are offering. The collected information will not tell us which website provides for the richest information. An alternative mode was needed to rank these websites.

The normal method of ranking a website is to measure the amount of visitors to a particular website. Ranking of websites by determining the number of visitors will yield information about the popularity of the created site. The higher the traffic, the more popular it is. Ranking like this could be useful if the purpose is to entice companies to advertise their goods or services on the website. There are many companies that offer tracking devices to monitor the flow of traffic on a website. These devices are sometimes embedded in a website that allows real-time data about traffic to a site to be collected. Using traffic data is useful but it does not give us a sense of the usefulness of the information provided to a prospective tourist who wishes to know more about potential tourism sites that he or she will be visiting.

Due to limitation of existing measures and the uniqueness of the indigenous home-stays websites, we decided to develop our own instrument to measure the richness of information for tourism related website to potential customers. The instrument was developed based on the type and amount of information available at the three websites which were the subject of this research. On analyzing the content of these websites, we found several recurring categories that are useful from the perspective of the users of the information. Thus, we decided to create a specialized instrument to analysis the content for the various websites. The instrument should yield information about the richness of the content. The websites that obtained the highest score will be ranked as the top-most website in terms of usability. In other words, it has the richest content. A higher ranking website will offer the best and most useful information to the user.

The steps taken to create the instrument are as follows. Firstly, we took notes of the types of information available on all the websites and create distinctive categorizes for each of them. Secondly, we create a rubric to rate the usefulness of the information for each category from poor, average, good and excellent. The rubric for the instrument is available in the appendix A of this paper.

These categories were created to rank the websites are as follows:

- About us - information relating to the owner or owners of a home-stay.

- Accommodation - information about the various types of accommodation available for rental

- Meals - information about the various types of meal provided to visitors of the home-stays

- Amenities - information about the type of toilet and bathing facilities provided by the home-stays.

- Packages - information about the types of tour/room and board packages provided by the home-stays.

- Popular destinations - information about tourist or nature sites within walking distance from the home-stays.

- $\quad$ Picture gallery - pictures about the place, people, past visitors and places of interest with or without captions.

- Contact - information on how to make a reservation or any queries to the operators of the home-stays.

- Guestbook - a place where previous visitors can offer their opinion and review about the home-stays. Guest will note down when they visited the place and offer unedited reviews about the home-stays.

- Trip Advisor - an international tourism website that offers a place for anyone to review a tourist site, place or lodging that they have stayed previously. Anybody can give a review and offer a subjective ranking about a previously visited site. The website allows reviewer five options from terrible to excellent to rank a particular tourism site.

\section{Results: The Most Usable Websites}

The types of information offered by the three websites are not similar, although all of them were providing the same kind of service: home-stays. The usefulness of these websites depends solely on the creativity of the owners or third party operators who are being paid to operate and continuously monitor them. Owners who are IT savvy will understand the benefit of registering a specific name as their domain. A search on Google using the search "longhouse homestay" or "Annah Rais" offers a glimpse into the expertise of the website owners. Using both keywords on Google, we found that Annah Rais Longhouse Adventure beat the other two home-stays operators to emerge top.

Updating of information is serious business for any websites. The currency of the information will indicate the seriousness of the owners about maintaining and sustaining their websites. The analysis of the various websites 
for this paper was carried out again on January 1, 2016. Two similar analyses were done with a time frame of six months apart. The repeated testing was done to see whether the websites were updated continuously. The latest analyses on the three longhouse home-stays operators yield the following information on the last updating of information:

- Bidayuh Annah Rais Longhouse Homestay, last updated January 12, 2012

- Borneo Sarawak: Annah Rais Bidayuh Homestay, last updated 2013

- Annah Rais Longhouse Adventure, last updated 2015

Judging by the latest year of updates, we can determine that only one website operators have made serious attempt to ensure that their website remains up-to-date. The most current is Annah Rais Longhouse Adventure. An updated website means that every visitor will be able to obtain the latest information about the home-stays provider. An outdated website will cast an unfavorable light on the home-stays operators. The least updated home-stays website belongs to Bidayuh Annah Rais Longhouse Homestay. Minimal updating of information has been done to the website that is hosted on blogspot.com. The last update was done in 2012. This does not augur well for the home-stays operators because people depend on the quality and currency of information to ascertain the suitability of a site to visit, especially if they intend to stay there overnight.

With our specially created instrument, we did the analysis based on what is available on these websites. In our computation, we found that two of the websites obtained an above average score and one website below the range of good. The scores for Annah Rais Longhouse Adventure, Annah Rais Bidayuh Homestay and Bidayuh Annah Rais Longhouse Homestay are 27, 25 and 17 respectively.

Annah Rais Longhouse Adventure's website obtained the highest score because of several factors. The Annah Rais Longhouse Adventure website is also linked to several other websites which are related to the tourism industry. Links with other websites are very important in exposing websites to a wider and specialized audience. Links allow the uninitiated web surfers to gain access to the website from a secondary site.

The findings indicate that potential visitors will obtain sufficient knowledge about each home-stays' packages and services if they were to surf the respective websites. Giving sufficient information does not necessarily be enough for a home-stays operator who wants to aggressively promote their services. The findings from this study indicate that they are still rooms for improvement.

One area of improvement will be to get more satisfied customers to share their opinion about their experience staying at the respective home-stays. Potential clients tend to believe what other customers who stayed there have to say. We have always valued word-of-mouth from other happy and satisfied people. Thus, it is necessary for these home-stays operators to publish as many positive comments as possible. These comments should be regularly updated. This is a form of free advertising that will give the most desirable impact for the home-stays operators.

Picture gallery should be made a prominent component of home-stays websites. Operators should make an effort to collect and publish pictures of guests as they go through the various activities at the home-stays. These pictures will tell the prospective client what to expect. Pictures of guests who are smiling are another method to give an impression of satisfied customers.

Amenities are another area of concern that all the home-stays operators have neglected to highlight in their websites. Home-stays providers are not operating like any conventional hoteliers where every hotel room will have their own attached bathroom. A home-stay operator should inform prospective clients that they have ample piped-water and electrical supplies. The existence of other facilities like fan, kitchen, refrigerator, televisions and other items should also be made known to customers. Information such as these will allow the customers to make an informed judgment about what to expect.

Another area is getting guests to comment on their experiences staying at these home-stays. A guest at Annah Rais Longhouse Adventure had this to say:

The longhouse if (sic) of the Bidayuh tribe. At the beginning they'll offer you Tuak (a local rice wine) as much as you can drink. Then there is a room with skulls from the old head hunting days.

A few of the houses are still in their old, traditional state but due to modernization some of the house have been renovated and made with modern materials (Aloysies 2015).

A good review on Tripadvisor which is a dedicated website that promotes all kinds of tourist spots and accommodation is like having a full-page write-up in the local daily or tourism magazine. Tripadvisor website 
has a distinct advantage because it is accessible 24-hours daily. Another visitor to Annah Rais Longhouse Adventure offered the following comments:

Was hesitant to do this trip but after reading the trip advisor reviews I am so glad we did. The host is very informant with great stories to tell. He let us drink as much of his home brew (moonshine) as we liked which was delicious. The hike to the hot springs was hot and a little long if you are not fit, but we loved it. The swim when you get there is so worth it. Our tracker that took us to the springs was so adorable and humble and he cooked us a traditional bamboo chicken in a piece of bamboo on an open fire. Night time dress ups was fun and so was the entertainment and local dancing. The host's wife cooked that evening and I can honestly say (from a fussy eater) that it was one of the BEST meals I have ever had. It was all organic and locally grown, including ingredients from the bush. The room was hot and damp smelling so had a restless night and we had cold showers, but for the overall experience and to get out of your comfort zone I would highly recommend doing this trip (Nadean, 2015)

The unedited review is worth more than the edited comments appearing on Annah Rais Longhouse Adventure website. An example is given here:

"I have three children, 10, 8 and 3 (almost 4) and they hiked, climbed, crossed the bridges, waded in the rivers, rafted, and bathed in the waterfalls. Not unreasonably difficult. The tour of the longhouses was educational and informative. Great for outdoors lovers and adventure seekers." - Yow \& families, Singapore (Longhouse Adventure, 2015)

The edited version does not state when the Yow's family spent their time at the longhouse. While it is good from the perspective of the home-stays operator, it leaves the impression that the information provided could have been doctored. A better alternative is to get the satisfied customers to write their comments on specially created feedback cards. A snapshot of the card with the comments written in the original handwritings of the pleased customers can be published on the website.

\section{Discussion and Conclusion}

Information about the location, accommodation, types of packages and the various methods of making and confirming a reservation are offered to surfers of websites. The richness of the provided information will entice would be visitors to the Annah Rais longhouses. The information provided by home-stays operators will have to be tailored to the needs of the prospective clients. Operators should not provide information need from their perspective. People from overseas will rely on the information provided on these websites to help them in the decision-making process. The analyses tell us which website has the most useful information. This should be translated as the best home-stays provider.

Prospective visitors will normally surf websites that display all the information necessary for them to help their decision-making process. Thus, website creators must use carefully chosen categories that are easily understood and related to the services provided. This information should be classified under standard heading menu on the homepage of the website. A website that uses a standard menu will allow surfer to check and compare all the information across the various websites. Surfers who are knowledgeable and IT savvy will normally check several similar websites at once. Thus, it will be an advantage to the home-stays operators that they use standardized menu header for their websites. The important menu headers are home, about us, accommodation, packages, booking or reservation, reviews and links.

"Home" is the standard header on any website. This is the first page or the homepage for a site. This allows any user to go back to the front page of the website with one click of the mouse. Without this header, the surfer will have to click backspace of the browser to go back to the homepage. Surfers will easily be frustrated and tend to move to another site if they find themselves lost in the maze of web pages.

The homepage should display content relating to the home-stays and activities that visitors can do during their stay. Pictures are the most important elements of informing prospective visitors of the place and surrounding area. Homepages should also highlight the cultural significance of visiting the home-stays. Home-stays visitors are usually those who would like to get a taste of the local culture and cuisine. They are not interested in fancy city-tours; they prefer to go back to nature. They want to immerse themselves into the local culture.

Another good header to have on the menu is the "about us". This will allow the home-stays operators to tell their prospective audience about who is managing the "home". It is important that the operators are able to touch base with their clients on this page. They are looking for sincerity and trustworthiness. They will have to decide whether you are who you said you are. A home-stay is not a hotel and they are never run by professional 
inn-keepers. These homes are run by local people with or without knowledge of the hospitality industry. A picture of the owner is a definite must. People tend to rely on pictures, especially pictures of people. This will give the user instant gratification in terms of the authenticity of the proprietor.

The accommodation header is a definite must. Prospective visitors will like to know how the sleeping quarters will be like. A representative picture of the various rooms available is a must. Home-stays visitors understand they will be sleeping in "someone" home. Thus it is best the home-stays operators give the information immediately. Putting this information on some other menu will be a disservice.

"Packages" is a definite must have as a header menu. This will inform your prospective clients about the various packages on offer. The more precise and detailed the various packages available will allow the visitors to make an informed decision. They will definitely compare the various packages available across different home-stays operators within the same locality.

After deciding on which home-stay, the last important menu on the website should be "booking" or "reservation". Only one of the home-stays operators uses this header. These are the words that people are accustomed to when planning a stay at a hotel or any rented accommodation. To use any other header, such as "contact us" will not be useful to the home-stays operators. It will be a disservice to an operator if they decide not to have such a menu.

The "reviews" header menu is something that private homes operators should seriously think of having on their website. This is where people who had stayed at a home-stay can share their experience with other people. Having a place where these people can load their pictures of their stay will help other people to decide. People tend to believe what other people have to say about the place. Operators should attract more people to upload information and pictures and interact on this page. Reviews should be free from any forms of editing, especially from the website admin. Any forms of editing will take away the authenticity of the comments. Some websites are reluctant to allow guest to comments friendly. Admin should accept this as fair comment and take action to improve on any shortcoming. They could post their reply to any unfavorable comments. This is what interactivity with our clients is all about.

"Links" is also an important header menu. A good website will always be linked to other websites that have the same objectives. Home-stays operators know the value of linking their website to a designated government agency for the promotion of tourism. The most useful link will be international organization that promotes tourism activities, such as Tripadvisor.

Future studies need to be done to confirm whether information provided by user-creator providers of tourism related website is reflective of what is actually offered on-site. Content providers who are also users of the Internet determine what can, will, and shall be provided. Their action will affect the trustworthiness, integrity and verity of the information. To determine elements of trustworthiness, integrity and verity, it will involve researcher visiting the actual tourism site to determine the accuracy of information provided on these websites. Alternatively, a survey can be carried with those who have stayed at the home-stays to determine whether they are satisfied with the provided information gathered from the websites, before and after staying at these home-stays.

\section{Acknowledgments}

The study was conducted with a grant from the Ministry of Higher Education, Malaysia.

\section{References}

Aloysies. (2015). A glimpse of life on a longhouse. Tripadvisor.com.my. Retrieved January 1, 2015, from https://goo.gl/LSUyTP

ALsarayreh, M. N., Jawabreh, O. A. A., ALkharabsheh, K. S., \& Aldahamsheh, M. M. (2011). Tourism Promotion through the Internet (Websites) (Jordan as a Case Study). Asian Social Science, 7(6), 125-135. http://dx.doi.org/10.5539/ass.v7n6p125

Amir, J. (2015). Masyarakat Melanau di Sarawak. Kuala Lumpur: Institut Terjemahan dan Buku Malaysia.

Baty, R. M., \& Dold, E. (1977). Cross-cultural homestays: An analysis of college students' responses after living in an unfamiliar culture. International Journal of Intercultural Relations, 1(1), 61-76. http://dx.doi.org/10.1016/0147-1767(77)90007-4

Flanagin, A. J., \& Metzger, M. J. (2000). Perceptions of internet information credibility. Journalism and Mass Communication Quarterly, 77(3), 515-540. http://dx.doi.org/10.1177/107769900007700304

Hamzah, A. (2007). Malaysian homestays from the perspective of young Japanese tourists: The quest of 
Furusato. In J. Cochrane (Ed.), Asian Tourism: Growth and Change (pp. 193-207). London: Routledge.

Henderson, J., Chan, Y. Z., Loke, F., \& Teo, F. (2004). Widening Accommodation Choice: The Potential of Homestay in Singapore. Asean Journal on Hospitality and Tourism, 3(1), 1-10.

Hokanson, S. (2000). Foreign Language Immersion Homestays: Maximizing the Accommodation of Cognitive Styles. Applied Language Learning, 11(2), 239-264.

Huang, W.-T., \& Ho, H.-F. (2015). Media Effectiveness on Commodity Purchase Behavior of University Students in Taiwan. Asian Social Science, 11(4), 378-385. http://dx.doi.org/10.5539/ass.v11n4p378

Ibrahim, Y. (2004). Research Note: Homestay Program in Malaysia - Development and Prospect. Asean Journal on Hospitality and Tourism, 3(1), 40-50.

Lin, Y.-S., \& Huang, J.-Y. (2006). Internet blogs as a tourism marketing medium: A case study. Journal of Business Research, 59, 1201-1205. http://dx.doi.org/10.1016/j.jbusres.2005.11.005

Longhouse Adventure. (2015). Reviews: What others say about us - Comments from our guests! Retrieved January 1, 2015, from http://www.longhouseadventure.com/reviews/

Meric, F., Bernstam, E. V., Mirza, N. Q., Hunt, K. K., Ames, F. C., Ross, M. I., ... Singletary, S. E. (2002). Breast cancer on the world wide web: cross sectional survey of quality of information and popularity of websites. Britain Medical Journal, 324-577. http://dx.doi.org/10.1136/bmj.324.7337.577

Musa, G., Kayat, K., \& Thirumoorthi, T. (2009). The Experiential Aspect of Rural Home-Stay among Chinese and Malay Students Using Diary Method. Tourism and Hospitality Research, 10(1), 25-41. http://dx.doi.org/10.1057/thr.2009.26

Nadean. (2015). Interesting. Great host. The best meal I have had in Malaysia. Tripadvisor.com.my. Retrieved January 1, 2015, from https://goo.gl/EDH8yn

Nielsen, J. (2000). Designing Web Usability. Indianapolis, Indiana: New Riders Publishing.

Samani, M. C. (2012). Penerbitan: Teori dan Praktis. Kota Samarahan: Penerbit Universiti Malaysia Sarawak.

Samani, M. C., Amin, L., \& Rezali, N. I. (2011). Using media to educate public on biotechnology. Procedia Social and Behavioral Sciences, 15, 2360-2364. http://dx.doi.org/10.1016/j.sbspro.2011.04.108

Samani, M. C., Bala, P., Maliki, J., \& Haris, R. (2013). Bario Community Radio: Engaging people making news. 8th International Conference on Information Technology in Asia - Smart Devices Trend: Technologising Future Lifestyle, Proceedings of CITA 2013.

Samat, T. P. (2012). Ethnic Tourism and the Bidayuh of Sarawak, Malaysia: A case study of Annah Rais village (M.A. Thesis). LaTrobe University, Australia.

Samat, T. P., Marwan, N. H., Samani, M. C., \& Maliki, J. (2014). Preserving Bidayuh Arts through Ethnic Tourism. Paper presented at 4th Regional Conference on Local Knowledge. Kuching, Sarawak. Oct 12-13.

Tsai, W.-H., Chou, W.-C., \& Lai, C.-W. (2010). An effective evaluation model and improvement analysis for national park websites: A case study of Taiwan. Tourism Management, 31, 936-952. http://dx.doi.org/10.1016/j.tourman.2010.01.016

Wall, G., Long, V., \& Butler, R. (1996). Balinese homestays: an indigenous response to tourism opportunities. In R. Butler, \& T. Hinch (Eds.), Tourism and indigenous people (pp. 27-48). London: Routledge.

\section{Appendix A}

Instrument to rank the richness of information on tourism related website

Name of website:

\begin{tabular}{|c|c|c|c|c|c|}
\hline \multirow[b]{2}{*}{ Categories } & \multicolumn{4}{|c|}{ Quality of information } & \multirow[b]{2}{*}{ Score } \\
\hline & Poor (1) & Average (2) & Good (3) & Excellent (4) & \\
\hline About us & $\begin{array}{l}\text { No description, } \\
\text { one picture }\end{array}$ & $\begin{array}{c}\text { One sentence } \\
\text { description of the } \\
\text { operator. One }\end{array}$ & $\begin{array}{c}\text { Three sentences } \\
\text { description of the } \\
\text { operator that includes }\end{array}$ & $\begin{array}{l}\text { Four or more sentences of } \\
\text { the operator that includes } \\
\text { location, history of the }\end{array}$ & \\
\hline
\end{tabular}




\begin{tabular}{|c|c|c|c|c|}
\hline & & picture & $\begin{array}{l}\text { location. Two to three } \\
\text { pictures }\end{array}$ & $\begin{array}{c}\text { place. Four of more } \\
\text { pictures }\end{array}$ \\
\hline Accommodation & Not stated & $\begin{array}{c}\text { Single mattress } \\
\text { and pillows place } \\
\text { on the floor }\end{array}$ & $\begin{array}{c}\text { Mattress, pillows, } \\
\text { cover sheets and } \\
\text { blankets }\end{array}$ & $\begin{array}{l}\text { Single and double beds, } \\
\text { mattress, pillows, cover } \\
\text { sheets and blankets }\end{array}$ \\
\hline Meals & Not provided & Breakfast only & Breakfast and dinner & $\begin{array}{l}\text { Breakfast, lunch and } \\
\text { dinner }\end{array}$ \\
\hline Amenities & $\begin{array}{c}\text { No toilet } \\
\text { facility/no } \\
\text { mention of any } \\
\text { toilet facilities }\end{array}$ & $\begin{array}{c}\text { Shared toilet } \\
\text { outside of facility }\end{array}$ & $\begin{array}{l}\text { Shared toilet within the } \\
\text { facility }\end{array}$ & $\begin{array}{c}\text { Separate toilet facilities in } \\
\text { each room }\end{array}$ \\
\hline Packages & $\begin{array}{c}\text { One type of tour } \\
\text { package }\end{array}$ & $\begin{array}{c}\text { Two to three tour } \\
\text { package }\end{array}$ & $\begin{array}{c}\text { Four to five tour } \\
\text { package }\end{array}$ & $\begin{array}{c}\text { More than six tour } \\
\text { package }\end{array}$ \\
\hline $\begin{array}{c}\text { Popular } \\
\text { destinations }\end{array}$ & Not clearly stated & $\begin{array}{c}\text { One to two places } \\
\text { of interest located } \\
\text { nearby }\end{array}$ & $\begin{array}{c}\text { Three places of interest } \\
\text { located nearby }\end{array}$ & $\begin{array}{c}\text { Four places of interest } \\
\text { located nearby }\end{array}$ \\
\hline Picture gallery & $\begin{array}{l}\text { None/no specific } \\
\text { picture gallery }\end{array}$ & $\begin{array}{c}\text { One to five } \\
\text { pictures }\end{array}$ & $\begin{array}{c}\text { Six to ten pictures with } \\
\text { captions }\end{array}$ & $\begin{array}{c}\text { Eleven or more pictures } \\
\text { with captions }\end{array}$ \\
\hline Contact & $\begin{array}{l}\text { Third party } \\
\text { contact }\end{array}$ & $\begin{array}{l}\text { Owners' } \\
\text { telephone }\end{array}$ & $\begin{array}{c}\text { Owners' telephone and } \\
\text { email }\end{array}$ & $\begin{array}{l}\text { Owners' telephone, } \\
\text { mobile phones, email, } \\
\text { fax, postal address }\end{array}$ \\
\hline Guestbook & $\begin{array}{l}\text { Comments made } \\
\text { by a visitors three } \\
\text { or more years ago }\end{array}$ & $\begin{array}{l}\text { Comments made } \\
\text { by a visitor } \\
\text { two-years ago }\end{array}$ & $\begin{array}{l}\text { Comments made by a } \\
\text { visitor last year }\end{array}$ & $\begin{array}{l}\text { Comments made by a } \\
\text { visitor this year }\end{array}$ \\
\hline TripAdvisors & One & $\begin{array}{c}\text { Two to five } \\
\text { reviews }\end{array}$ & Six to ten reviews & Eleven or more reviews \\
\hline \multicolumn{5}{|c|}{ Total Score } \\
\hline
\end{tabular}

\section{Copyrights}

Copyright for this article is retained by the author(s), with first publication rights granted to the journal.

This is an open-access article distributed under the terms and conditions of the Creative Commons Attribution license (http://creativecommons.org/licenses/by/4.0/). 